\title{
CANDIDATES IN THE PRESIDENTIAL ELECTIONS IN ROMANIA (2014): THE USE OF SOCIAL MEDIA IN POLITICAL MARKETING
}

\author{
Monica Pătrut \\ “Vasile Alecsandri” University of Bacău \\ monicapatrut@yahoo.com
}

\begin{abstract}
The phenomenon of social media has drawn the attention of the specialists from the political marketing because it contributes quickly and efficiently to the increase of the political product's visibility and appeals to its supporters for content creation and viral promotion of the political messages. In addition, the candidate can communicate directly with the citizens and may involve them in creating virtual communities. In our study we briefly present the way in which social media was used, timidly at first, during the campaign for the 2008 parliamentary elections, for the 2009 presidential elections and for the 2012 local and parliamentary elections. The importance of social media increased during the 2012 Romanian presidential impeachment referendum and contributed decisively to rallying voters to go to the polls and, implicitly, to the Klaus Iohannis's victory in the 2014 presidential elections. We have focused especially on Facebook, as social network, because it has managed to attract the largest number of users in Romania. The success of the 2.0 political actors does not imply (only) to use the network as an alternative news channel, but especially to establish the bidirectional connection and constant interaction with virtual friends.
\end{abstract}

\section{Keywords}

presidential elections; political marketing; social media; Facebook; Romania; 2014

\section{JEL Classification}

M31

\section{New times, new campaigns!}

Progress in the field of technology and communications has brought about a considerable increase of the importance of the online environment in political marketing, while maintaining the traditional campaign tools which continue to play a significant role. In literature, there is shift from the 20th century campaign pattern to the 21st century typical campaign (Johnson, 2011). Even if between the two patterns there are still continuity elements and an evolutionary process, the change of paradigm is considered to have been carried out in the USA by the Republican Bob Dole who, during the 1996 presidential debate urged voters to visit his campaign website.

"The 20th century pattern" focused more on the political consultants in shaping the strategy and messages, emphasized the top-bottom communication and did not involve too many activists and voters in the carrying out the election campaign, allocating television the dominant position in the election campaign communication area. Although there were surveys and public debates, the election strategy was built on the consultants' intuition, instinct and experience. Campaign financing was ensured by the major donors and voters were mere spectators having as single task to be present to vote.

"The online revolution" supported by the new and social media has marked the shift to "the 21st century pattern" and showed its effectiveness starting from the US 
presidential elections in 2008 (Mihalache, 2012). This pattern is much more fluid and allows the citizens' involvement. Although it keeps television as a means of communication, it places the online component in the centre of the campaign. Johnson (2011) insists that "as the online component of the campaign has started to consolidate, campaigns have realized the importance to have a network administrator, a blog specialist, a social network manager, a group of online publicity, a staff for the online campaign of strategic importance equivalent to any other components of the campaign". These campaigns are carried out continuously and at fast pace, also joining small donors that can contribute online or by sms, involving and rallying voters/volunteers who can share their time, ideas, money and energy in the campaign. This new pattern offers the best prerequisites for a greater public participation in the political life (Lees-Marshment, 2009).

\section{Social media and 2.0 political actor}

\subsection{Social media - a brief introduction}

Social media refers to those environments we use for social interaction, which use as platforms the Internet and mobile technologies and enable communication according to many-to-many (Ulmanu, 2011). Following another definition, social media is built on three key-elements: the content created by the user, the communities and the Web 2.0 technologies (Ahlqvist,Bäck, Halonen \& Heinonen, 2008). Content creation and participation become interesting when there are other people who do this. People have the ability to communicate directly, to interact and to create real virtual communities. Digital technologies specific to the Web 2.0 era facilitate users to participate in these activities. In the same theoretical direction, Heinonen \& Halonen (2007) define social media as tools, spaces and operation modes for people who interact with one another, create, share, change and comment on contents in the virtual communities and social networking. Social Media may take several forms, including forums on the Internet, weblogs, blogs, wikis and podcasts, video, photos, social-bookmarking. According to Andreas M. Kaplan \& Michael Haenlein (2010) there are six different types of social media: collaborative projects (Wikipedia), (micro)blogs, content communities (Bookcrossing, Flickr, YouTube, Slideshare), social networking sites (Facebook, LinkedIn, and MySpace), virtual worlds games (World of Warcraft) and virtual communities (Second Life).

The explosive and attractive phenomenon called social media is explained by the Heinonen \& Halonen (2007) using a metaphor. Starting from the idea of the representation of the digital society as a human hand, authors consider that each of the five fingers represents a topic (identity, recognition, confidence, belonging and creativity) and the palm (empowerment) is the ability resulting from the contribution of the five fingers. For each individual, social media is a tool to help themselves to express their identity, to receive recognition from the other members of virtual community, and this fact stimulating them to participate more in the community life and create content, to become more confident and to remain faithful to social networks or to discover new ones. Belonging to these communities cannot be achieved without the individuals' motivation and skills to connect, to communicate, to make a choice between the various existing networks and communities and to demonstrate their creativity by posting new contents. Together, the five fingers empower the hand to participate successfully in the digital life. 


\subsection{Social media - a hybrid element of the promotion mix}

Entirely agreeing with Mangold \& Faulds (2009), we believe that social media has produced changes in the classical marketing paradigm and has become a hybrid element of the promotion mix because it enables businesses/ organizations to speak with customers/targets and, at the same time, customers/ targets to communicate between them- an extension of traditional word-of-mouth communication. In the old paradigm, the integrated marketing communication (IMC) aimed at transmitting a coherent message to customers by coordinating all the elements of the promotion mix - advertising , personal sale, public relations, direct marketing and sales promotion. In the new paradigm (see fig. 1), social media have improved their tools and strategies to communicate with customers/targets (Castronovo \& Huang, 2012), giving them the status of credible source of information on products, services, companies as well as pressure factor on businesses/ organizations for improving the offered services.

Figure 1. Social media and the new paradigm for marketing communication

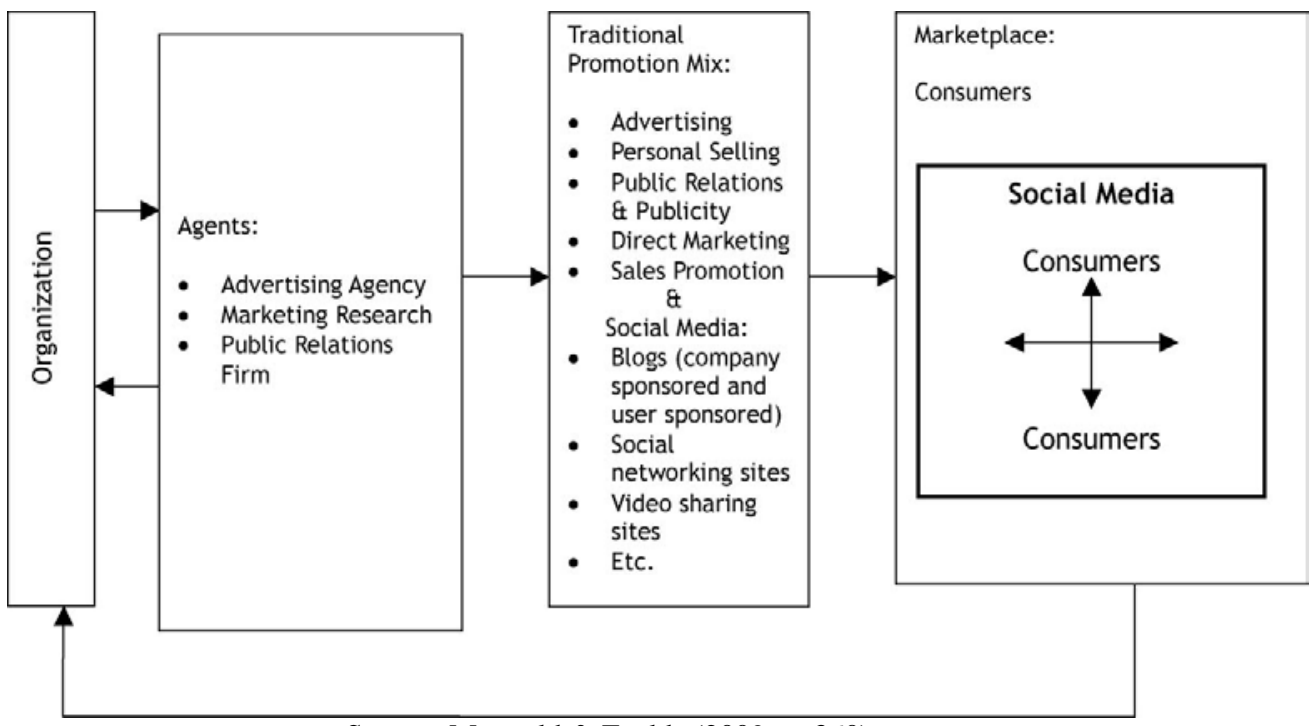

Source: Mangold \& Faulds (2009, p. 360)

After social media was successfully integrated by the commercial marketing in the new communication paradigm, it is the turn for political marketing to offer it the same importance. Candidates in many countries have integrated social media into their communication strategies and this has also contributed to their success in the campaign. Research in the past few years has shown that politicians have appealed especially to social networking sites, the most popular being Facebook, Twitter, MySpace. Using social networking sites (SNS) candidates have sent citizens political messages and tried to involve them in a two-way communication with the political elites (Cogburn \& Espinoza-Vasquez, 2011). Citizens are encouraged on social network sites to "create their own political content, distribute it online, and comment on the content created by others" (Hanson et al, 2010). They also have generated online involvement and offline activism by facilitating face-to-face meetings with supporters and connections between supporters, and managed in some cases to create virtual volunteering communities (Vitak et al, 2011), attracted funds and donations (Hanson et al, 2010). SNS represented an opportunity for candidates to reach people less interested in politics (Utz, 2009) and to control the message transmitted by posting, deleting or editing some campaign messages or by providing further 
clarification if a message was misunderstood by journalists or citizens (Bor, 2014). SNS have helped to humanize candidates, to turn them into genuine and accessible people (Slotnick, 2009), to understand the electorate's needs and views (Larsson, 2015, p.2). Taking advantage of this technology, the candidates' campaign staff have collected a lot of personal data and, after their analysis, they could not send personalized messages, changed the calendar, content, or channel through which these messages reached safely and quickly to recipients (Cogburn \& Espinoza-Vasquez, 2011). In addition, by interesting, simple or amusing/tormenting messages sent to the candidates and redistributed by the citizens in their own social networks we have come to the "viral distribution" (Klinger \& Svensson, 2014) and to globalization topics or campaign issues by means of this technology era specific to the Web 2.0 era.

\section{Social media - a political marketing tool (also) in Romania}

\subsection{Social media - a concise story of their faint early beginning.....}

Its first timid uses took place during the electoral campaign for the 2008 parliamentary elections ((Pătruţ, 2011; Pătruţ, 2012) and in the 2009 presidential elections (Aparaschivei, 2011; Bosoteanu, 2012; Momoc, 2011; Holotescu et al., 2011). At that time, social media helped to promote the image of the political actor to rally supporters to vote (Momoc, 2011). Even if some Romanian politicians entered into the virtual game, they interacted less with their online friends. Romanian MPs chose to post on Facebook impersonal official messages, information and images related to their activities in the Parliament or Party, family photos and of trips, and they very seldom interacted directly with their friends from the list, possible supporters and voters. In 2012, local and parliamentary elections took place in Romania. In both campaign, candidates used social media to launch self-promoting messages and attacking topics, to rally supporters to vote and to avoid uncomfortable debates in the election campaign. (Pătruţ \& Pătruţ, 2013; Pătruţ, 2013a). The blogosphere and Facebook network fragmented the virtual space, the candidates isolating themselves according to ideology, thus the online channel operated less as a platform for debate, but more as a political PR tool (Momoc, 2013).

Social Media became more dynamic, more interactive in 2012 also on the occasion of the second Romanian presidential impeachment referendum when Facebook turned into an arena to fight for the opponents and supporters of the president in office. Using photos, posters and posts, through praises and attacks, the two opposite parties were able to involve all the virtual friends in assessing, commenting and distributing the political information, especially during and at the end of electoral period (Pătruţ, 2014).

In order to show the dynamic feature of social media during the referendum, we have included in our analysis not only Facebook, the social network which has held the monopoly in the online environment, but also other platforms created during the election campaign, the best-known being: http://www.legea-junglei.ro, www.demitel.ro, www.davotez.ro, www.totuldesprebasescu.com. We used as a model for the analysis the honeycomb pattern taken from Kietzmann, Hermkens, McCarthy \& Silvestre (2011) and adapted it to the available information. This pattern emphasizes the fact that the central block of digital interaction is constituted by six peripheral blocks: presence, sharing, relationships, reputation, groups and conversation.

On Facebook, the virtual groups / communities were formed according to a single criterion: to be (By the side of our president, You are you angry with Basescu? Why?, The Torch of Democracy.) or not to be with the president Traian Basescu (The Torch of Democracy 2, Fed up with Traian Basescu, The Country is burning. Give a Like if 
you were disappointed with Traian Basescu, Yes, for the dismissal of Basescu!). Being mainly open, these groups managed to attract many members and they were able to operate as a true aggregator of political opinions on the space axis and during the entire election campaign and as an 'opinion barometer' valid for the virtual environment (Pătruţ, 2013b). Sharing is seen as a way to interact in the virtual environment and refers to the exchange process between users, exchange consisting in receiving and delivering content. By analyzing the number of these shares, as it can be seen in Table 1 , the pro president group was more active than the one against president, the former sharing materials in the network 38,403 times, and the latter only 33,817 times.

Table 1. Groups set up on Facebook during the 2012 referendum

\begin{tabular}{|l|l|l|l|l|}
\hline Nume of the group & Type & Likes & Comments & Shares \\
\hline By the side of our president & Open & 339,866 & 60,342 & 34,231 \\
\hline $\begin{array}{l}\text { You are you angry with } \\
\text { Basescu? Why? }\end{array}$ & Open & 17,994 & 12,255 & 4,171 \\
\hline The Torch of Democracy & Closed & 1900 & 80 & 10 \\
\hline The Torch of Democracy 2 & Open & 267 & 75 & 162 \\
\hline Tired of Traian Basescu, & Open & 1109982 & 2238 & 27055 \\
\hline $\begin{array}{l}\text { The Country is burning. } \\
\text { Give a Like if you were } \\
\text { disappointed with Traian } \\
\text { Basescu }\end{array}$ & 5945 & 2198 & 4352 \\
\hline $\begin{array}{l}\text { Yes, for the dismissal of } \\
\text { Basescu! }\end{array}$ & Open & 4500 & 1022 & 2248 \\
\hline \multicolumn{2}{|l|}{ Source: Pătrut M. (2013b, p.847) } \\
\hline
\end{tabular}

Conversations between Facebook users, members in the analyzed groups, have been an indicator of the fact that this campaign managed to capture and rally the active electorate on the network. The number of comments generated is high: 72,605 generated by the pro-president group and 5,533 belonging to the opponent group. The analysis of these comments shows us that in the social media there was a real preoccupation to talk more than the opponent. Relationships define the manner in which users refer to one another in the virtual environment, exchanging information, joining each other or chatting, meeting or just appearing on the friends' list. The Facebook pages analyzed show that the relationships between users worked to a limited extent and only if the users shared the same political beliefs. For example, the group entitled Fed up with Basescu still referred to groups which militated for president dismissal: Dismiss him.ro, Are we cleaning up the politics?, Basescu down!, Bye, bye Basescu!, PDL Mafia!. Social Media was an effective tool used in the election campaign for the presidential dismissal referendum in 2012. Both sides involved in the election competition invested in online platforms to increase the campaign' efficiency and reach the young audience. The posted campaign materials managed to rally and involve internauts in carrying out the election campaign or citizen responsibility awareness campaigns advertised in order to be able to exercise the vote. Based on the materials posted, on the analyzed groups arguments were supplied by the campaign staff, arguments that met only with others provided by the users sharing the same political beliefs. Unfortunately, the two political sides and their corresponding groups represent within the virtual environment isolated islands 
which do not communicate with each other, without allowing opponents the dialogue, exchange of arguments or counter-arguments.

\section{2 .... to the important role in the election of the "Facebook president"}

The presidential elections held in 2014 began with 14 candidates, but the two finalists were Victor Ponta from the PSD+UNPR+PC Alliance (3,836,093 votes validly cast, i.e. 40.44\%) and Klaus Iohannis supported by the Christian Liberal Alliance $(2,881,406$ votes validly cast, i.e. $30.37 \%)$. If in the first round the situation was rather clear, in the second round things took an unexpected turn, Iohannis, the candidate, managing to win the elections (6,288,789 votes validly cast, i.e. $54.43 \%)$ with an advance of 1,024,406 votes in front of his opponent, the prime minister Victor Ponta.

From the inside of the campaign staff, we found out that the whole campaign for Klaus Iohannis was designed to focus on the concept of authenticity, the latter being understood as a campaign devoid of rhetorical embellishments, of rejection of the negative messages and attacks from the opponents, with an emphasis on a positive campaign prevailing in the online environment and specifically aimed at young people in the urban areas who could be reached by social media (Mihalache \& Huiu, 2015). Social Media became a channel that could no longer be ignored, according to the existing data (www.facebrands.ro) 7 million citizens had a Facebook account in 2014.

The images with the citizens from abroad sitting at endless queues to vote in the first ballot, the doors of the embassies shut in front of the citizens who had not voted created excitement in online environment, were commented upon and distributed by members of the Facebook network. Judging by the number of fans for the two candidates, the number of posts or likes received, it might be asserted that Facebook was a faithful barometer for the current situation in the field.

In the last week of the campaign for the second round, Ponta had 715,332 fans and Iohannis 874,844, in the case of both opponents, all fans were from Romania and from the countries in which there are Romanian communities (see Table 2). During this period, Klaus Iohannis posted 110 messages which were rewarded with 3.746.977 likes, 180,914 comments and 462,234 shares. Victor Ponta posted 116 messages and received from fans only 1,200,445 likes, 159,439 comments and 105,913 shares. (Covaci, 2015).

Table 2. Fans' distribution on the two candidates according to the geographical criterion

\begin{tabular}{|l|l|l|l|l|l|}
\hline \multicolumn{3}{|c|}{ Victor Ponta } & \multicolumn{3}{c|}{} \\
\hline Country & No. of fans & $\begin{array}{l}\% \text { from the } \\
\text { total no. of } \\
\text { fans }\end{array}$ & Country & No. of fans & $\begin{array}{l}\text { \% from total } \\
\text { no. of fans }\end{array}$ \\
\hline Romania & 644,418 & $90.1 \%$ & Romania & 681,280 & $80.3 \%$ \\
\hline Italy & 15,734 & $2.2 \%$ & Italy & 44,117 & $5.2 \%$ \\
\hline Spain & 6,437 & $0.9 \%$ & Spain & 22,907 & $2.7 \%$ \\
\hline Germany & 4,291 & $0.6 \%$ & Germany & 21,210 & $2.5 \%$ \\
\hline U.K. & 5,006 & $0.7 \%$ & U.K. & 16,119 & $1.9 \%$ \\
\hline Moldova & 2,145 & $0.3 \%$ & Moldova & 7,635 & $0.9 \%$ \\
\hline U.S.A. & 2,145 & $0.3 \%$ & U.S.A. & 6,787 & $0.8 \%$ \\
\hline France & 2,145 & $0.3 \%$ & France & 6,787 & $0.8 \%$ \\
\hline
\end{tabular}

Source: Tănase, 2015, p.101 
Before the second round of elections, there had created the event pages on Facebook by which the Romanians in the country and those in the diaspora were invited to get out in the street to support the constitutional right to vote. The various reported irregularities or personal impressions about the way in which elections ensued in the polling stations in the country or abroad were shared on Facebook. There were rallying and ideological motivation campaigns coordinated by means of Facebook, the best-known being the vote-rallying campaign: Let's make ourselves heard!

On the Election Day, Klaus Iohannis had 35 posts and Victor Ponta 18 posts. Regarding engagements, Klaus Iohannis had the fans' engagement three times higher than his opponent's, which proved to be decisive in winning the competition both in the online environment, and at the polls. The lucky turnover in this case was that of the engaged users, of the unique people who interacted uniquely with Klaus Iohannis's Facebook page. On the night after winning the elections, Iohannis posted the following message on Facebook: "Together, we have won the battle here on Facebook! Thank you very much for this victory! You are now the largest community formed around a politician in the online environment! Together, so many and so strong, we're unbeatable! Today we have won! .... You have written history! For the first time, the online has made a difference".

The study conducted by the Romanian Institute for Assessment and Strategy (Romanian abbreviation IRES) shows that 32\% of the interviewees went to vote after incidents at the voting boxes in the diaspora, and $42 \%$ said that they had a family member or a friend abroad and their advice in connection with their vote was decisive. 54\% of interviewees said that they used the Internet, and most of them (93 $\%)$ are present on Facebook. $70 \%$ of those who use the Internet consider that the internet and social networks influenced the participation to vote, $13 \%$ sent or redirected the election messages or election campaign and on the internet, $24 \%$ gave "like" to some pages or messages of the candidates in the presidential elections. In conclusion, the study underlines that "the convergence between Facebook, television and mobile telephony was the recipe which led to the great rallying to vote in the second round" and thus, ensuring Klaus Iohannis's victory in the presidential elections.

\section{Conclusions}

Social media has offered unexpected opportunities to the political candidates: helping them to communicate with the voters, organize face-to-face meetings with supporters and create connections between supporters, attract funds and donations, send messages in real time and at very low costs, involve citizens in the message creation and their viral sharing, introduce themselves to virtual friends as cautious, careful people sensitive to the needs of their fellows.

The 2.0 political marketing pattern implemented by B. Obama's political campaign team in 2008 started, steadily but firmly, to grow in Romania as well. The 2014 presidential campaign showed how important it is for a successful candidate to hold the central position in a social network, to communicate mutually with the citizens and have a constant interaction with them. The political actor either communicates in the social media or disappears.

\section{References}

Ahlqvist, T., Bäck, A., Halonen, M., Heinonen, S (2008). Social media road maps exploring the futures triggered by social media. VTT Tiedotteita - Valtion 
Teknillinen Tutkimuskeskus (2454), available at http://www.vtt.fi/inf/pdf/tiedotteet/2008/T2454.pdf.

Aparaschivei, P. (2011). "The Use of New Media in Electoral Campaigns: Analysis on the Use of Blogs, Facebook, Twitter and YouTube in the 2009 Romanian Presidential Campaign”, Journal of Media Research, Vol. 2 (10) 39-60.

Bor, S.E. (2014), Using Social Network Sites to Improve Communication.

Between Political Campaigns and Citizens in the 2012 Election, American Behavioral Scientist, 58(9) 1195-1213.

Boşoteanu, I.C. (2012). New media. Rolul new media în campania electorală prezidenţială din 2009, Iaşi: Institutul European.

Castronovo, C., Huang, L., (2012). Social Media in an Alternative Marketing Communication Model, Journal of Marketing Development and Competitiveness, vol. 6(1), 117- 131.

Cogburn, D. L., \& Espinoza-Vasquez, F. K. (2011). From networked nominee to networked nation: Examining the impact of Web 2.0 and social media on political participation and civic engagement in the 2008 Obama campaign. Journal of Political Marketing, 10, 189-213.

Covaci, M. (2015). Factorul Facebook în alegerile prezidenţiale, Sfera politicii 1(183), 85 -92, available at http://www.sferapoliticii.ro/sfera/183/art08Covaci.php.

Hanson, G., Haridakis, P., Cunningham, A., Sharma, R., \& Ponder, J. D. (2010). The 2008 presidential campaign: Political cynicism in the age of Facebook, MySpace, and YouTube, Mass Communication \& Society, 13(5), 584-607.

Heinonen, S. \& Halonen, M. (2007). Making Sense of Social Media. Interviews and Narratives. SOMED Foresight Report 2. Espoo, Finland, available at http://owela.vtt.fi/owela/ uploads/2007/11/making-sense-of-social-media-vtt-r04539-07.pdf.

Holotescu, C., Guţu, D., Grosseck, G., Bran, R.(2011). Microbolgging Meets Politics. The Influence of Communication in 140 Characters on Romanian Presidential Elections in 2009, Romanian Journal of Communication and Public Relations, 13 (21), 37-46.

Institutul Român pentru Evaluare şi Strategie (2015). Generaţia Facebook şi convergenţa media au dus la victoria lui Klaus Iohannis. Studiu post-electoral privind motivaţiile alegătorilor în turul al doilea al alegerilor prezidenţiale, available at_http://www.ires.com.ro/articol/282/genera-ia-facebook-\%C8\%99iconvergen\%C8\%9Ba-media-au-dus-la-victoria-lui-klaus-iohannis.

Johnson, D.W. (2011), Campaigning in the Twenty-First Century. A Whole New Ballgame? , New York and London: Routledge.

Kaplan, A., Haenlein, M. (2010). Users of the world, unite! The challenges and opportunities of social media, Business Horizons, 53(1), 58- 68.

Kietzmann, J. H.,Hermkens,K., McCarthy,I.P. and Silvestre, B.S. (2011). Social media? Get serious! Understanding the functional building blocks of social media, Business Horizons, 54, 241-251.

Klinger, U. \& Svensson, J. (2014). The emergence of network media logic in political communication: a theoretical approach. New Media \& Society 18: 1-19.

Lees-Marshment, J.(2009). Political Marketing. Principles and Applications. London and New York: Routledge.

Larsson, A.O. (2015), Going viral? Comparing parties on social media during the 2014 Swedish election, Convergence: The International Journal of Research into New Media Technologies, 1-16.

Mangold, W.G., Faulds, D.J., (2009), Social media: The new hybrid element of the promotion mix, Business Horizons 52, 357-365. 
Mihalache, D. (2012), Curs de marketing politic, Bucureşti, Universitatea Creștină "Dimitrie Cantemir".

Mihalache, D., Huiu, I. (2015). Alegerile prezidențiale din 2014 - rezultat surpriză sau strategie. Sfera politicii 1(183), 29-40, available at http://www.sferapoliticii.ro/sfera/183/art09-Tanase.php.

Momoc, A. (2011). Candidaţii populişti şi noile tehnologii (Blog, Facebook, YouTube) în alegerile prezidenţiale din 2009", Sfera Politicii, 8 (162), 39-47 available at http://www.sferapoliticii.ro/sfera/162/art05-Momoc.php.

Momoc, A. (2013). "Romanian Parliamentarians on social media. Mobilizing voters at the poll in the 2012 parliamentary campaign" în Pătruț, Monica, Pătruț, Bogdan (editori), Web 2.0 in Education and Politics. The Social Media Revolution, Ed: Lambert Academic Publishing, Saarbrücken, pp. 422-448.

Pătruţ, M (2011), Blogul - un instrument pentru democratizarea comunicării electorale?, Sfera politicii 5(159), 57-65 available at http://www.sferapoliticii.ro/sfera/159/art07-Patrut.php.

Pătruţ, M (2012), Website-ul partidului - instrument de comunicare politică. Studiu de caz: www.psd.ro, Sfera politicii 3 (169), 145-155 available at http://www.sferapoliticii.ro/sfera/169/art14-Patrut.php.

Pătruţ, M., Pătruţ, B. (2013), Facebook - Communication Tool in Local Elections Campaign. Case Study: Bacău, 2012 in Monica Pătruț, Bogdan Pătruţ (eds.) Web 2.0 in Education and Politics. The Social Media Revolution, Lambert Academic Publishing, Saarbrücken, pp. 420- 435.

Pătruţ, M. (2014), Facebook Dispute concerning the Presidency. Case Study: Romania, 2012, în Bogdan Pătruţ, Monica Pătruţ (eds). Social Media in Politics: Case Studies on the Political Power of Social Media, Springer, pp. 245-256.

Pătruţ, M. (2013a), The Analysis of Parliamentary Faces during Election Campaigns: Case Study: Bacau, 2012 în Bogdan Pătruţ (coord.)., International Conference SMART 2013. Social Media in Academia: Research and Teaching, Editura Medimond, Monduzzi Editore International Proceedings Division, pp. 283289.

Pătruţ, M (2013b), A fi sau a nu fi preşedinte in social media? in The Proceedings of the European Integration-Between Tradition And Modernity Congress,

Editura Universităţii "Petru Maior", Volume Number 5, pp.842-850 available at http://www.upm.ro/facultati_departamente/stiinte_litere/conferinte /situl_integrare_europeana/Lucrari5/IETM5_Part100.pdf.

Popescu, C. (2005). Publicitatea: o estetică a persuasiunii, Bucureşti: Editura Universităţii din Bucureşti.

Slotnick, A. (2009). "Friend" the president: Facebook and the 2008 presidential election. In C. Panagopoulos (Ed.), Politiking online: The transformation of election campaign communications. (pp. 249-271). New Brunswick, NJ: Rutgers University Press.

Tănase, T. (2015). The electoral campaign through Social Media. Case Study - 2014 Presidential elections in Romania. Sfera politicii 1(183), 92-105, available at http://www.sferapoliticii.ro/sfera/183/art09-Tanase.php

Ulmanu, A.B. (2011). Cartea feţelor. Revoluţia Facebook în spaţiul social. Bucureşti: Humanitas.

Utz, S. (2009). The (potential) benefits of campaigning via Social Network Sites. Journal of Computer-Mediated Communication, 14, 221-243.

Vitak, J., Zube, P., Smock, A., Carr, C. T., Ellison, N., \& Lampe, C. (2011). It’s complicated: Facebook users' political participation in the 2008 election. Cyberpsychology, Behavior, and Social Networking, 14(3), 107-114. 